\title{
Prevalence of nonsyndromic oral clefts in a reference hospital in the state of Minas Gerais, Brazil, between 2000-2005
}

\author{
Prevalência de fissuras orais não-sindrômicas \\ em um hospital de referência no estado de \\ Minas Gerais, Brasil, entre 2000 e 2005
}

\author{
Hercílio Martelli-Junior ${ }^{(a)}$ \\ Letícia Vieto Porto (b) \\ Daniella Reis Barbosa Martelli(d) \\ Paulo Rogério Ferreti Bonan ${ }^{\text {(a) }}$ \\ Amanda Beatriz Freitas $(\mathrm{c})$ \\ Ricardo Della Coletta ${ }^{(\mathrm{e})}$
}

(a) PhDs, Professors of Oral Pathology; (d) Specialist and Researcher - School of Dentistry, State University of Montes Claros.

(b)DDS; (c) Graduate Student and ResearcherCenter for the Rehabilitation of Craniofacial Anomalies, José do Rosário Vellano University, Alfenas.

(e) PhD, Professor, Department of Oral Diagnosis, School of Dentistry, State University of Campinas.

\begin{abstract}
The aim of the present study was to analyze the prevalence of nonsyndromic oral clefts in children receiving treatment at the Center for the Rehabilitation of Craniofacial Anomalies, José do Rosário Vellano University, Alfenas, MG, Brazil. All the data for the epidemiological study was retrieved from the files of 126 pediatric patients with oral clefts without any additional malformation, who came to the center for treatment between 2000 and 2005. A predominance of clefts was observed in Caucasians, and the ratio of male to female was 1.3. Males were 2.57 times more affected by cleft lip and palate (CLP) than females. CLP with a prevalence of $39.68 \%$ and isolated cleft lip (CL) with a prevalence of $38.09 \%$ were the most common anomalies, followed by isolated cleft palate (CP; $22.23 \%$ ). Complete and unilateral CLP $(26.19 \%)$ presented the highest prevalence, followed by incomplete and unilateral CL $(23.81 \%)$. The present study presents the experience of a reference hospital in the state of Minas Gerais; however, the real prevalence of oral clefts in Brazil is still unknown. Our findings differ from those of a few previous Brazilian reports because they suggest similar prevalences of CLP and CL, and a higher prevalence of CLP in Caucasian males.
\end{abstract}

Descriptors: Cleft palate; Cleft lip; Epidemiology.

Resumo: O objetivo do presente estudo foi analisar a prevalência de fissuras orais nãosindrômicas em crianças que receberam tratamento no Centro de Reabilitação de Anomalias Craniofaciais da Universidade José do Rosário Vellano, Alfenas, MG, Brasil. Todos os dados epidemiológicos deste estudo foram obtidos dos arquivos de 126 pacientes pediátricos com fissuras orais sem outra malformação adicional que compareceram ao Centro para tratamento entre 2000 e 2005 . O predomínio das fissuras foi observado em caucasianos e a relação entre homens e mulheres foi de 1,3 . Os homens foram 2,57 vezes mais atingidos por fissuras lábio-palatais (FLP) do que as mulheres. FLP com prevalência de $39,68 \%$ e fissuras labial isolada (FL) com prevalência de $38,09 \%$ foram as anomalias mais comuns, seguidas por fissuras palatinas isoladas (FP, 22,23\%). As FLP completas e unilaterais $(26,19 \%)$ foram as de maior prevalência, seguidas por FL incompletas e unilaterais $(23,81 \%)$. O presente estudo mostrou a experiência de um Hospital de Referência em Minas Gerais; contudo, a verdadeira prevalência de fendas orais ainda é desconhecida. Nossos achados divergem dos de alguns poucos estudos anteriores por demonstrar prevalências similares de FLP e FL, e um acometimento maior de FLP em caucasianos do sexo masculino.

Descritores: Fenda palatina; Fenda labial; Epidemiologia.
Received for publication on Sep 25, 2006 Sent for alterations on Jan 12, 2007 Accepted for publication on May 17, 2007 


\section{Introduction}

Clefts of the lip and/or palate account for $65 \%$ of all head and neck anomalies, and can be found as an isolated finding or in association with other features, as part of syndromes. ${ }^{4}$ The etiology and pathogenesis of oral clefts, particularly of nonsyndromic origin, remain poorly understood. This is in part a reflection of the complexity and diversity of the molecular mechanisms involved during embryogenesis, with both genetic and environmental factors playing an influential role. ${ }^{8}$

Epidemiologic studies of isolated clefts, such as cleft lip (CL) and cleft palate (CP), or the combination of both (cleft lip-palate, CLP) have been conducted worldwide, often resulting in varying prevalence rates. ${ }^{7}$ Differences in geographic and ethnic distributions may explain some of the prevalence variations but not all. The incidence in European Caucasian populations ranges from 1 to 2.21 per 1,000 livebirths, ${ }^{6}$ among individuals with the same ethnical origin. In Brazil, there is a paucity of studies on oral clefts in children. The few published studies came from the Hospital for the Rehabilitation of Craniofacial Anomalies, University of São Paulo, Bauru, SP, Brazil. Studies from this center revealed a prevalence of oral clefts of 0.19 per 1,000 livebirths, ${ }^{5}$ and a predominance of complete CLP in females. ${ }^{1,3}$ The Center for the Rehabilitation of Craniofacial Anomalies, University of Alfenas (José do Rosário Vellano University), Alfenas, MG, Brazil was established in 1992 and has attended more than 1,500 patients presenting craniofacial malformations, especially oral clefts. The purpose of this study was to analyze the prevalence of oral clefts in patients that received treatment in this hospital from 2000 to 2005.

\section{Material and Methods}

The study sample consisted of 126 children that were referred to the Center for the Rehabilitation of Craniofacial Anomalies, University of Alfenas (José do Rosário Vellano University), Alfenas, MG, Brazil, between the years 2000 and 2005. Clinical examination included classification of the cleft type according to the classification previously proposed by Spina et al. ${ }^{9}$ (1972). Clefts were classified in CL,
CP or CLP, and sub-classified in complete or incomplete and in unilateral or bilateral. Patients with previous history of surgical procedure for correction of the malformation were excluded from the study in order to avoid misclassification. Patients with recognizable syndromes or rare clefts were also excluded. The study protocol was approved by the Ethics in Research Committee, School of Dentistry, José do Rosário Vellano University. All patients's parents or guardians were informed about the study's purpose before they consented to participate. The chi-square test was performed considering 0.05 as statistically significant, and all types of variables (gender, race and types of clefts) were analyzed using their subclassification.

\section{Results}

Table 1 describes the clinical features, according to gender and race, of the patients affected by nonsyndromic oral clefts of this study. From 126 children, $71(56.35 \%)$ were males and $55(43.65 \%)$ were females (M/F ratio 1:1.3). Oral clefts were found to be more frequent in Caucasians than in non-Caucasians $(85.72 \%$ and $14.28 \%$ respectively). Gender was not a predictive factor for prevalence. As recommended by the World Health Organization (WHO), $85 \%$ of the patients received treatment before the age of one year. The other patients $(15 \%)$ received treatment after two up to ten years of age. Interestingly, most patients were characterized as belonging to the lowest socioeconomic class. CLP accounted for the highest proportion of the cases (39.68\%), followed by CL in 48 patients $(38.09 \%)$ and $\mathrm{CP}$ in 28 patients $(22.23 \%$ ) (Table 2$)$. The prev-

Table 1 - Distribution of the 126 patients affected by nonsyndromic oral clefts of this study according to gender and race.

\begin{tabular}{|c|c|c|c|c|}
\hline \multicolumn{2}{|c|}{ Evaluated Variables } & $\mathrm{n}$ & Prevalence (\%) & Chi-Square \\
\hline \multirow{2}{*}{ 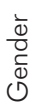 } & Male & 71 & 56.35 & \multirow{2}{*}{$\begin{array}{l}\chi^{2}=2.02 \\
p=0.15^{*}\end{array}$} \\
\hline & Female & 55 & 43.65 & \\
\hline \multirow{2}{*}{$\stackrel{\mathscr{v}}{\stackrel{0}{\alpha}}$} & Caucasian & 108 & 85.72 & \multirow{2}{*}{$\begin{array}{l}\chi^{2}=64 \\
p<0.001^{\text {** }}\end{array}$} \\
\hline & Non-Caucasian & 18 & 14.28 & \\
\hline
\end{tabular}

${ }^{*}$ non-significant difference. ${ }^{* *}$ significant difference. 
alence of isolated CL and isolated CP was similar between genders, but CLP prevalence in males was 2.57 times higher than in females (Table 2). A heterogenous distribution was clearly evident as demonstrated by the Chi-Square test.

Complete and unilateral CLP $(26.19 \%)$ was the most prevalent oral cleft, followed by incomplete and unilateral CL $(23.81 \%)$ and incomplete CP (18.26\%) (Table 3). Incomplete and unilateral CL was the most frequent type of cleft in this group, comprising $62.5 \%$ of the isolated clefts in the lip (Table 3). Furthermore, unilateral CLs were 7 times more frequent than bilateral CLs, whereas an incomplete involvement of the lip was 2.2 times more frequent than a complete involvement. Incomplete $\mathrm{CP}$ was 4.6 times more frequent than complete $\mathrm{CP}$, accounting for $82.14 \%$ of the CP cases (Table 3). Unilateral clefts of the lip and palate simultaneously and completely were more frequent than the bilateral occurrence of this type of malformation $(66 \%$ and $34 \%$ respectively) (Table 3). In table 3, all differences were significant.

Table 2 - Prevalence of nonsyndromic oral clefts in children according to gender.

\begin{tabular}{l|c|c|c|c}
\hline & $\begin{array}{c}\text { Male } \\
\mathrm{n}(\%)\end{array}$ & $\begin{array}{c}\text { Female } \\
\mathrm{n}(\%)\end{array}$ & $\begin{array}{c}\text { Total } \\
\mathrm{n}(\%)\end{array}$ & Chi-Square \\
\hline $\begin{array}{l}\text { Cleft } \\
\text { Lip-Palate }\end{array}$ & $36(72)$ & $14(28)$ & $50(39.68)$ & $\begin{array}{l}\chi^{2}=7.04 \\
\mathrm{p}=0.0296^{*}\end{array}$ \\
\hline $\begin{array}{l}\text { Cleft Lip } \\
\begin{array}{l}\text { Cleft } \\
\text { Palate }\end{array}\end{array}$ & $25(52.08)$ & $23(47.92)$ & $48(38.09)$ & - \\
\hline
\end{tabular}

*significant difference.

\section{Discussion}

It is now well established that the several types of oral clefts are epidemiologically different, which is probably dependent on ethnicity. ${ }^{11}$ Although a great number of epidemiological studies on oral clefts have been published around the world, there are few that have been carried out in Brazil. Furthermore, studies such as the present one provide insight into the prevalence of oral cleft of different population groups, which can be useful for government planning of new strategies for medical care of oral cleft patients.

The findings of the present study reveal that, of the 126 children with nonsyndromic oral clefts, the prevalence of CLP and isolated CL was quite similar, with 50 patients $(39.68 \%$ ) having CLP and 48 patients $(38.09 \%)$ having CL. The remaining 28 patients $(22.23 \%)$ had CP. In most published studies, the percentage of subjects with CLP has been higher compared to that of $\mathrm{CL}$ or $\mathrm{CP}$ alone, including the Brazilian studies. ${ }^{1,3}$ Barbosa et al. ${ }^{1}$ (2003) described an incidence significantly higher of CLPs $(65.5 \%)$ compared to that of isolated CLs $(18.2 \%)$ and isolated CPs (16.3\%). Similarly, another recent Brazilian study demonstrated a higher prevalence of complete CLP, either unilateral or bilateral, compared to that of isolated clefts. ${ }^{3}$ These differences may be due to the race blending between African-Brazilian and Caucasian individuals, which is very common in Brazil; however, a conclusion based on small samples in association with limited knowledge on the etiology of the oral clefts is tenuous.

\begin{tabular}{|c|c|c|c|c|c|c|}
\hline \multirow{4}{*}{$\begin{array}{r}\text { Table } 3 \text { - Overall and } \\
\text { group prevalence of } \\
\text { the different types of } \\
\text { oral clefts. }\end{array}$} & \multirow{2}{*}{\multicolumn{2}{|c|}{ Type }} & & & & \\
\hline & & & \multirow{2}{*}{$\begin{array}{l}n \\
5\end{array}$} & \multirow{2}{*}{$\begin{array}{c}\text { Prevalence in the } \\
\text { group (\%) } \\
17.86\end{array}$} & \multirow{2}{*}{$\begin{array}{c}\text { Overall } \\
\text { Prevalence (\%) } \\
3.97\end{array}$} & \multirow{3}{*}{$\begin{array}{l}\text { Chi Square } \\
\begin{array}{l}\chi^{2}=11.57 \\
p<0.001^{*}\end{array}\end{array}$} \\
\hline & \multirow{2}{*}{$\begin{array}{l}\text { Isolated } \\
\text { Cleft Palate }\end{array}$} & Complete & & & & \\
\hline & & Incomplete & 23 & 82.14 & 18.26 & \\
\hline & \multirow{4}{*}{$\begin{array}{l}\text { Isolated } \\
\text { Cleft Lip }\end{array}$} & Complete Unilateral & 12 & 25 & 9.52 & \multirow{4}{*}{$\begin{array}{l}\chi^{2}=40.5 \\
p<0.001^{*}\end{array}$} \\
\hline & & Incomplete Unilateral & 30 & 62.5 & 23.81 & \\
\hline & & Complete Bilateral & 3 & 6.25 & 2.38 & \\
\hline & & Incomplete Bilateral & 3 & 6.25 & 2.38 & \\
\hline & \multirow{2}{*}{$\begin{array}{l}\text { Cleft } \\
\text { Lip-Palate }\end{array}$} & Complete Unilateral & 33 & 66 & 26.19 & \multirow{2}{*}{$\begin{array}{l}\chi^{2}=5.12 \\
p=0.0237^{*}\end{array}$} \\
\hline & & Complete Bilateral & 17 & 34 & 13.49 & \\
\hline
\end{tabular}

*significant difference. 
The study presented here also revealed that the unilateral involvement of the CLP is more frequent than the bilateral involvement, as well as the unilateral involvement in isolated CL. There was a significantly higher number of patients with incomplete CL, i. e. involvement of either lip or alveolar bone, compared to the number of patients with complete CL. Interestingly, Freitas et al. ${ }^{3}$ (2004) found that complete CL was the most frequent type of cleft in this group, comprising $20 \%$ of the clefts on the left side and $15.3 \%$ on the right side. In the group of patients with isolated CP, an incomplete involvement of either hard palate or soft palate was more prevalent than a complete involvement of both palates, a finding which is similar to that presented by Freitas et al. ${ }^{3}$ (2004) and other studies. ${ }^{8,10}$

Gender distribution showed an overall male predominance (M/F ratio 1:1.3), which was significantly increased in the CLP group (M/F ratio 1:2.57). Furthermore, Caucasians represented more than $85 \%$ of the patients affected by nonsyndromic oral clefts in this study. A tendency towards the Caucasian male prevalence has been reported previously in several studies including a Brazilian one., ${ }^{2,3}$ On

\section{References}

1. Barbosa MM, Rocha CM, Katina T, Caldas M, Codorniz A, Medeiros C. Prevalence of congenital heart diseases in oral cleft patients. Pediatr Cardiol. 2003;24(4):369-74.

2. Derijcke A, Eerens A, Carels C. The incidence of oral clefts: a review. Br J Oral Maxillofac Surg. 1996;34(6):488-94.

3. Freitas JA, Dalben G da S, Santamaria M Jr, Freitas PZ. Current data on the characterization of oral clefts in Brazil. Braz Oral Res. 2004;18(2):128-33.

4. Gorlin R, Cohen M, Hannekam R. Syndromes of the head and neck. $4^{\text {th }}$ ed. New York: Oxford University Press; 2001.

5. Loffredo L, Freitas J, Grigolli A. Prevalência de fissuras orais de 1975 a 1994. Rev Saúde Pública. 2001;35(6):571-5.

6. Magdalenic-Mestrovic M, Bagatin M. An epidemiological study of orofacial clefts in Croatia 1988-1998. J Craniomaxillofac Surg. 2005;33(2):85-90.

7. Mitchell LE, Beaty TH, Lidral AC, Munger RG, Murray JC, Saal HM et al. Guidelines for the design and analysis of the other hand, isolated CP has been described as significantly more prevalent in Brazilian females, ${ }^{1,3}$ which was not observed in our study.

\section{Conclusions}

In summary, the present study showed that complete and unilateral CLP was the most frequent oral cleft among a group of Brazilians treated in a reference hospital in the state of Minas Gerais, Brazil. Furthermore, the prevalences of CLP and isolated CL were very similar, but higher than that of isolated CP, and Caucasian males were more frequently affected than females. Our study also points to the need to establish a national cleft registry to ensure reliable recording of patients with these congenital anomalies.

\section{Acknowledgments}

The authors would like to thank the members of the Center for the Rehabilitation of Craniofacial Anomalies, José do Rosário Vellano University, Alfenas, MG, Brazil. We would also like to thank the National Council for Scientific and Technological Development (CNPq), Brazil.

studies on nonsyndromic cleft lip and cleft palate in humans: summary report from a Workshop of the International Consortium for Oral Clefts Genetics. Cleft Palate Craniofac J. 2002;39(1):93-100.

8. Murray JC. Gene/environment causes of cleft lip and/or palate. Clin Genet. 2002;61(4):248-56.

9. Spina V, Psillakis JM, Lapa FS, Ferreira MC. [Classification of cleft lip and cleft palate. Suggested changes]. Rev Hosp Clin Fac Med Sao Paulo. 1972;27(1):5-6.

10. Vallino-Napoli LD, Riley MM, Halliday J. An epidemiologic study of isolated cleft lip, palate, or both in Victoria, Australia from 1983 to 2000. Cleft Palate Craniofac J. 2004;41(2):18594.

11. Wantia N, Rettinger G. The current understanding of cleft lip malformations. Facial Plast Surg. 2002;18(3):147-53. 